DOI : https://doi.org/10.24843/JFU.2020.v09.i03.p02

pISSN: 2301-7716; eISSN: 2622-4607

Jurnal Farmasi Udayana, Spesial Issue Desember 2020, 144-151

\title{
POTENSI ANTIOKSIDAN SEDIAAN NANOPARTIKEL EKSTRAK KERNEL BIJI LIMUS (Mangifera foetida Lour)
}

\author{
Nurviana, V., Alifiar, I., Wulandari, W. T., Dewi, R., Nuraeni, R. \\ Prodi Farmasi Sekolah Tinggi Ilmu Kesehatan Bakti Tunas Husada Tasikmalaya \\ Jl. Cilolohan No. 36, TasikmLaya, Jawabarat, Indonesia, 46115, Telp. (0265) 334740, Fax. (0265) \\ 327224 \\ E-mail:veranurviana@stikes-bth.ac.id
}

Riwayat artikel: Dikirim: 06/10/2020; Diterima: 28/10/2020, Diterbitkan: 31/12/2020

\begin{abstract}
The antioxidants are compounds that have the ability to inhibit free radical activity that causes degenerative diseases. One source of natural ingredients known to have antioxidant activity is limus (Mangifera foetida Lour.), One of mango species from the Anacardiaceae tribe which is a local Indonesian fruit. Limus seed kernel extract (EBL) has been shown to have antioxidant activity. Antioxidant activity can be increased by making nanoparticle preparations. This study aims to increase the antioxidant activity of limus seeds by modifying the extract into nanoparticle preparations. The preparation of nanoparticles was carried out by the ionic gelation method and to ensure the formation of extract nanoparticles, characterization was carried out including particle size, polydispersion index and zeta potential value. The increase in antioxidant activity of limus seed extract (NEBL) nanoparticles was carried out by comparing the $\mathrm{IC}_{50}$ value with the $\mathrm{IC}_{50} \mathrm{EBL}$ value, and to see its potential by comparing it with vitamins. The method of measuring antioxidant activity used is the DPPH (2,2-diphenyl-1-picrylhydrazyl) method. $\mathrm{IC}_{50}$ data were analyzed using the One Way Annova test and post-hoc LSD test with a confidence level of 95\%. Based on the research results, it was obtained that limus seed extract nanoparticles were prepared which had characteristics including; The particle size was $2.91 \mathrm{~nm}$, the polydispersion index value was 0.456 and the zeta potential value was $+56 \mathrm{mV}$ and the $\mathrm{IC}_{50}$ value was $1.166 \pm 0.021 \mu \mathrm{g} / \mathrm{mL}$. The $\mathrm{IC}_{50}$ value of the $\mathrm{EBL}$ is $9.127 \pm 0.022 \mu \mathrm{g} / \mathrm{mL}$ and Vitamin $\mathrm{C}$ is $3.933 \pm 0.013 . \mu \mathrm{g} / \mathrm{mL}$ Modification of EBL into NEBL preparations can increase antioxidant activity and has excellent potential as a natural antioxidant because it has stronger antioxidant activity than vitamin $\mathrm{C}(\mathrm{p}<0.05)$.
\end{abstract}

Keywords: Antioxidant, Limus, Mangifera foetida Lour, Nonoparticle

\section{ABSTRAK}

Antioksidan merupakan senyawa yang memiliki kemampuan menghambat aktivitas radikal bebas penyebab timbulnya penyakit degeneratif. Salah satu sumber bahan alam yang diketahui memiliki aktivitas antioksidan adalah limus (Mangifera foetida Lour.), sejenis mangga dari suku anacardiaceae yang merupakan buah lokal Indonesia. Ekstrak kernel biji limus (EBL) telah diketahui memiliki aktivitas sebagai antioksidan. Aktivitas antoksidan dapat ditingkatkan dengan pembuatan sediaan nanopartikel. Penelitian ini bertujuan untuk mengupayakan peningkatan aktivitas antioksidan biji limus dengan memodifikasi ekstrak menjadi sediaan nanopartikel. Pembuatan sediaan nanopartikel dilakukan dengan metode gelasi ionik dan untuk memastikan terbentuknya nanopartikel ekstrak, dilakukan karakterisasi meliputi ukuran partikel, indeks polidispersi dan nilai zeta potensial. Peningkatan aktivitas antioksidan dari nanopartikel ekstrak biji limus (NEBL) dilakukan dengan cara membandingan nilai $\mathrm{IC}_{50}$-nya dengan nilai $\mathrm{IC}_{50} \mathrm{EBL}$, dan untuk melihat potensinya dilakukan dengan cara membandingkannya dengan Vitamin. Metode pengukuran aktivitas antioksidan yang digunakan adalah metode DPPH (2,2-diphenyl-1-picrylhydrazyl). Data $\mathrm{IC}_{50}$ dianalisis menggunakan uji One Way Annova dan uji lanjut Post-hoc LSD dengan taraf kepercayaan 95\%. Berdasarkan hasil penelitian, diperoleh sediaan nanopartikel ekstrak biji limus 
DOI : https://doi.org/10.24843/JFU.2020.v09.i03.p02

pISSN: 2301-7716; eISSN: 2622-4607

Jurnal Farmasi Udayana, Spesial Issue Desember 2020, 144-151

yang memiliki karakteristik meliputi; ukuran partikel 2,91 nm, nilai indeks polidispersi 0,456 dan nilai zeta potensial sebesar $+56 \mathrm{mV}$ dan nilai $\mathrm{IC}_{50}$ sebesar $1,166 \pm 0,021 \mu \mathrm{g} / \mathrm{mL}$. Nilai IC 50 dari EBL

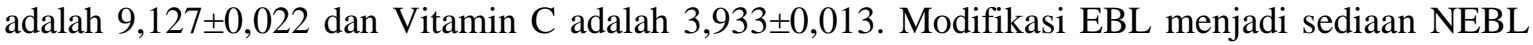
dapat meningkatkan aktivitas antioksidan dan memiliki potensi yang sangat baik sebagai antioksidan alami karena memiliki aktivitas antioksidan yang lebih kuat dibandingkan vitamin $\mathrm{C}(\mathrm{p}<, 05)$.

Kata kunci: Antioksidan, Limus, Mangifera foetida Lour, Nanopartikel.

\section{PENDAHULUAN}

Nanopartikel adalah partikel koloid dengan rentang ukuran 10-1000 nm. Nanopartikel terdiri atas bahan polimer dengan obat, enzim, atau antigen yang berada dalam keadaan terlarut, dijerat, dienkapsulasi, dan atau diabsorpsi (Agoes, 2008). Metode gelasi ionik adalah teknik sederhana dalam pembentukan nanopartikel. Pembentukan nanopartikel metode ini dilakukan dengan melarutkan kitosan (bermuatan positif) dalam asam asetat, kemudian dicampurkan dengan larutan polianionik (bermuatan negatif) seperti larutan natrium tripolifosfat (NaTPP). Nanopartikel dibentuk melalui reaksi kompleks antara senyawa bermuatan positif dan negatif selama pengadukan mekanis pada suhu kamar, menghasilkan pemisahan kitosan dalam partikel bulat dengan ukuran dan muatan permukaan yang berbeda (Munawar dkk, 2017).

Aplikasi nanopartikel pada bidang farmasi digunakan untuk mengatasi kelarutan zat aktif yang sukar larut, memperbaiki bioavailabilitas yang buruk, memodifikasi sistem penghantaran obat sehingga obat dapat langsung menuju daerah yang spesifik, meningkatkan stabilitas zat aktif dari degradasi lingkungan (penguraian enzimatis, oksidasi, hidrolisis), memperbaiki absorbsi suatu senyawa makromolekul, dan mengurangi efek iritasi zat aktif pada saluran cerna (Abdassah, 2017). Selain itu, nanopartikel dapat meningkatkan kestabilan dari senyawa yang labil seperti senyawa antioksidan (Mappamasing dkk, 2015).
Salah satu sumber antioksidan alami adalalah tanaman limus (Mangifera foetida Lour.). Limus merupakan tanaman herbal yang merupakan spesies buah mangga dari keluarga anacardiachae yang banyak terdapat di wilayah Indonesia. Salah satu bagian yang bermanfaat pada tanaman limus adalah biji. Ekstrak Biji buah limus memiliki aktivitas antioksidan yang kuat (Nurviana, 2018), dengan kandungan senyawa metabolit sekunder yaitu flavonoid, tannin, polifenol, monoseskuiterpen dan seskuiterpen, serta kuinon (Nurviana, 2016).

Berdasarkan latar belakang tersebut penelitian ini bertujuan untuk melakukan pembuatan sediaan nanopartikel ekstrak biji buah limus (Mangifera foetida Lour) sebagai upaya peningkatan aktivitas antioksidan dan mengetahui seberapa besar potensinya sebagai alternate antioksidan alami. Pengujian aktivitas antioksidan dilakukan secara in vitro dengan metode DPPH yang memiliki beberapa keuntungan yaitu mudah digunakan, mempunyai tingkat sensitivitas yang tinggi dan dapat menganalisis sampel dalam jangka waktu yang singkat (Kurniasih, 2018).

\section{BAHAN DAN METODE}

\subsection{Bahan dan Alat}

\subsubsection{Bahan}

Bahan yang digunakan adalah kernel biji Limus, etanol 96\%, kloroform, pereksi Mayer, Dragendroff, Seruk Zn, asam klorida, amyl alkohol, $\mathrm{FeCl}_{3}$, gelatin $1 \%$, pereaksi Liebermann Buchard, $\mathrm{NaOH}$, asam sulfat pekat, asam asetat, DPPH (1,1diphenyl-2-picrylhydrazyl) [Merck: SigmaAldrich], Asam Askorbat [Merck: Sigma- 
DOI : https://doi.org/10.24843/JFU.2020.v09.i03.p02

pISSN: 2301-7716; eISSN: 2622-4607

Jurnal Farmasi Udayana, Spesial Issue Desember 2020, 144-151

Aldrich], metanol, kitosan, Natrium Tripolifosfat (NaTPP), etil asetat, aqua deion dan aquadest.

\subsubsection{Alat}

Alat-alat yang digunakan dalam penelitian adalah timbangan analitik, spatula, cawan uap, alat gelas laboratorium, pipet tetes, maserator, waterbath, botol semprot, rotary evaporator, particle size analyzer (PSA), zeta sizer, spektrofotometer uv-vis, dan magnetic stirrer.

\subsection{Metode}

\subsubsection{Pengumpulan Bahan}

Bahan yang digunakan pada penelitian ini adalah kernel biji Limus (Mangifera foetida Lour) yang diperoleh dari daerah Tasikmalaya.

\subsubsection{Pembuatan Ekstrak}

Serbuk simplisia kernel biji Limus dimaserasi menggunakan etanol 96\% selama $3 \times 24$ jam pada suhu kamar. Ekstrak etanol yang diperoleh diuapkan pelarutnya menggunakan evaporator menghasilkan ekstrak etanol kental.

\subsubsection{Penapisan Fitokimia}

Penapisan fitokimia dilakukan untuk mengetahui kandungan senyawa metabolit sekunder yang terdapat pada tanaman, meliputi identifikasi golongan alkaloid, flavonoid, saponin, steroid dan triterpenoid, tanin dan polifenol, kuinon, mono dan seskuiterpenoid.

\subsubsection{Pembuatan Larutan Kitosan}

Pembuatan kitosan 0,5\% dilakukan dengan melarutkan 0,5 gram serbuk kitosan dalam $100 \mathrm{~mL}$ larutan asam asetat $2 \%$ menggunakan magnetic stirrer dengan kecepatan 1000 rpm selama 30 menit.

\subsubsection{Pembuatan Larutan Natrium Tiopolifosfat}

Larutan natrium tripolifosfat $0,01 \%$ diperoleh dengan cara melarutkan serbuk natrium tripolifosfat $0,01 \mathrm{~g}$ dalam $100 \mathrm{~mL}$ aquadeion menggunakan magnetic stirrer dengan kecepatan 1000 rpm selama 30 menit (Taurina, 2017).

\subsubsection{Pembuatan Nanopartikel}

Pembuatan nanopartikel ekstrak dilakukan dengan perbandingan ekstrak: kitosan: NaTPP yaitu 2: 1: 0,0035 mg/mL. Ekstrak dicampurkan dengan larutan kitosan dan dihomogenkan dengan magnetic stirrer pada kecepatan 1000 rpm selama 30 menit. Larutan NaTPP ditambahkan dalam larutan kitosan ekstrak pada temperatur ruangan dengan putaran magnetic stirrer pada kecepatan 1000 rpm selama 4 jam hingga terbentuk koloid nanopartikel. Setelah ini sediaan nanopartikel disonikasi selama 30 menit. Koloid nanopartikel yang dihasilkan dikarakterisasi menggunakan Particle Size Analyzer (PSA) dan Zeta Sizer untuk mengetahui ukuran partikel dan nilai zeta potensialnya.

\subsubsection{Uji Aktivitas Antioksidan secara In Vitro}

a. Pembuatan Larutan DPPH

Larutan pereaksi adalah larutan DPPH yang dibuat dengan menimbang $78,864 \mathrm{mg}$ serbuk DPPH kemudian dimasukkan ke dalam labu ukur $100 \mathrm{~mL}$ dan ditambah metanol sampai tanda batas. Dari larutan DPPH tersebut diambil sebanyak $10 \mathrm{~mL}$ dan diencerkan dengan metanol dalam labu ukur $100 \mathrm{~mL}$, sehingga didapatkan konsentrasi $0,2 \mathrm{mM}$ yang dihitung terhadap BM DPPH sebesar 394,32 g/mol.

b. Pembuatan Larutan Ekstrak Etanol Biji Limus

Pembuatan larutan stok ekstraks etanol biji limus dilakukan dengan cara melarutkan 100 mg ekstrak dilarutkan dalam metanol p.a hingga $100 \mathrm{~mL}$, sehingga diperoleh larutan stok $1000 \mu \mathrm{g} / \mathrm{mL}$ Seri kadar masing-masing sampel ditentukan berdasarkan hasil uji pendahuluan pengukuran antioksidan.

c. Pembuatan Larutan Nanopartikel Ekstrak 
DOI : https://doi.org/10.24843/JFU.2020.v09.i03.p02

pISSN: 2301-7716; eISSN: 2622-4607

Jurnal Farmasi Udayana, Spesial Issue Desember 2020, 144-151

Etanol Biji Limus

Sebanyak $100 \mathrm{mg}$ ekstrak yang dikonversi kedalam jumLah sampel uji ditimbang secara seksama, dimasukkan ke dalam labu ukur $100 \mathrm{~mL}$ dilarutkan dengan buffer asetat $\mathrm{pH}$ 5,5 lalu volumenya dicukupkan dengan metanol hingga mencapai volume $100 \mathrm{~mL}$ dengan konsentrasi $1000 \mu \mathrm{g} / \mathrm{mL}$ (konsentrasi 1\%). Larutan induk ini selanjutnya digunakan untuk pembuatan larutan uji pada seri konsentrasi. Seri kadar masing-masing sampel ditentukan berdasarkan hasil uji pendahuluan pengukuran antioksidan.

\section{d. Pembutan Larutan Induk Vitamin C}

Pembuatan larutan stok vitamin C dilakukan dengan cara melarutkan $100 \mathrm{mg}$ vitamin $\mathrm{C}$ dilarutkan dalam metanol p.a hingga $100 \mathrm{~mL}$, sehingga diperoleh larutan stok $1000 \mu \mathrm{g} / \mathrm{mL}$. Seri kadar masing-masing vitamin $\mathrm{C}$ ditentukan berdasarkan hasil uji pendahuluan pengukuran antioksidan.

\section{e. Penentuan Panjang Gelombang Maksimum Larutan DPPH}

Pengujian aktivitas antioksidan nanopartikel ekstrak biji buah limus diawali dengan penentuan panjang gelombang maksimum ( $\lambda$ maks) larutan DPPH $1 \mathrm{~mL}$ dalam $1 \mathrm{~mL}$ metanol menggunakan spektrofotometri UV-Vis. Larutan tersebut dibaca serapannya pada panjang gelombang 400-600 nm.

\section{f. Operating Time}

Penentuan operating time $1 \mathrm{~mL}$ larutan uji nanopartikel esktrak biji buah limus dilakukan dengan mencampurkan 1 mL larutan DPPH, dikocok homogen dan diamati serapannya sampai menit ke 60 . Kemudian ditentukan waktu operating time.

\section{g. Penentuan Absorbansi Peredaaman DPPH}

Sebanyak $1 \mathrm{~mL}$ larutan uji dicampurkan dengan $1 \mathrm{~mL}$ DPPH $(0,2 \mathrm{mM})$ kemudian divortex. Kembali dan diinkubasi pada suhu ruang di tempat gelap sesuai dengan operating time. Larutan ini selanjutnya diukur absorbansinya pada panjang gelombang yang telah didapatkan pada tahap sebelumnya dengan menggunakan spektrofotometer UV-Vis.

\section{h. Analisa Data}

Data yang diperoleh dari uji aktivitas antioksidan ekstrak etanol biji buah limus, nanopartikel ekstrak, dan vitamin $\mathrm{C}$ dengan metode DPPH adalah nilai absorbansi, kemudian dihitung persentase aktivitas antioksidan dengan rumus pada persamaan 1.

$\%$ inhibisi $=\frac{(\text { A blanko-A sampel })}{(\text { A blanko })} \times 100 \% \ldots . . .(1)$

Keterangan: $\mathrm{A}=$ Absorbansi

Nilai IC50 (Inhibition Concentration) dapat dihitung menggunakan persamaan regresi linier dari $\mathrm{y}=\mathrm{bx}+\mathrm{a}$ antara konsentrasi larutan uji, (x) dengan persentase aktivitas antioksidan, (y) dan dianalisis secara deskriptif (Mulangsri dkk, 2017).

Analisis data nilai $\mathrm{IC}_{50}$ yang digunakan pada penelitian ini adalah uji statistik One Way ANOVA. Perbedaan yang ada, dinyatakan dengan nilai $\mathrm{p}<0,05$. Data tersebut sebelumnya diuji normalitasnya menggunakan Shapiro-wilk. Uji lanjutan yang dilakukan adalah analisis Post-hoc LSD untuk menentukan tingkat perbedaan yang signifikan dari keseluruhan parameter uji.

\section{HASIL}

Hasil skrinning fitokimia ekstrak dan sediaan nanopartikel ekstrak etanol biji limus pada tabel 1, menunjukkan keberadaan senyawa-senyawa yang sering dilaporkan memiliki aktivitas antioksidan, seperti flavonoid, tanin, polifenol, kuinon dan senyawa terpen.

Hasil karakteristik sediaan nanopartikel ekstrak biji limus yang dihasilkan menunjukkan hasil yang baik dengan ukuran partikel $291 \mathrm{~nm}$, persen 


\section{Nurviana dkk}

DOI : https://doi.org/10.24843/JFU.2020.v09.i03.p02

pISSN: 2301-7716; eISSN: 2622-4607

Jurnal Farmasi Udayana, Spesial Issue Desember 2020, 144-151

intensitas sebanyak 99\%, nilai indeks polidispersi sebesar 0,456 , dan zeta potensial $+56 \mathrm{mV}$.

Pengujian aktivitas antioksidan pada penelitian ini menggunakan metode DPPH (1,1,2,2-diphenyl picryl hydrazyl). DPPH bertindak sebagai radikal bebas yang dapat bereaksi dengan senyawa yang dapat

Tabel 1 Hasil Skrining Fitokimia Simplisia dan Ekstrak

\begin{tabular}{ccc}
\hline \multirow{2}{*}{ Pengujian } & \multicolumn{3}{c}{ Hasil Pengujian } \\
\cline { 2 - 3 } & EBL & NEBL \\
Alkaloid & - & - \\
Flavonoid & + & + \\
Tanin & + & + \\
Tanin galat & + & - \\
Tanin katekat & - & + \\
Polifenol & + & + \\
Monoterpen & + & + \\
Siskuiterpen & + & - \\
Steroid & - & + \\
Triterpenoid & + & + \\
Kuinon & + & - \\
Saponin & - & \\
\hline Keterangan; EBL= Ekstrak Biji Limus, NEBL= Nanopartikel Ekstrak Biji Limus
\end{tabular}

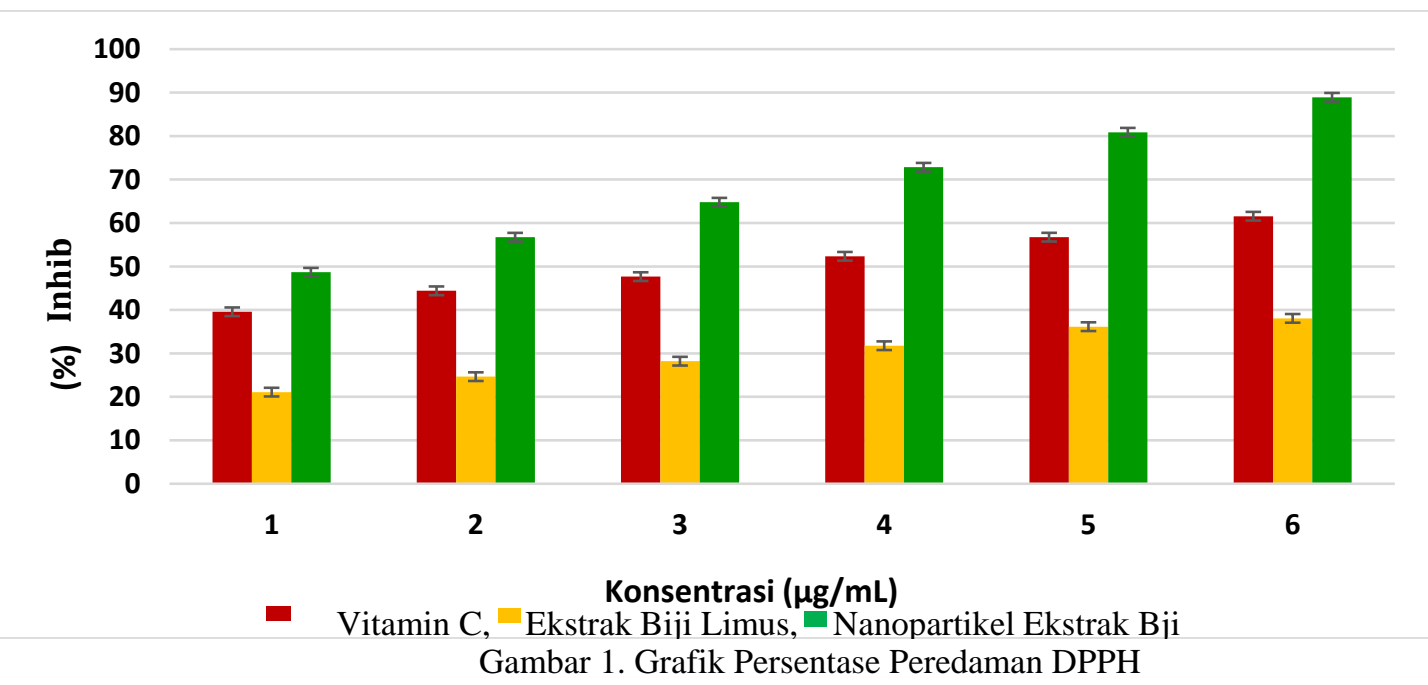

Tabel 2 Nilai IC50 Vitamin C, Ekstrak, dan Nanopartikel Ekstrak Biji Limus

\begin{tabular}{ccc}
\hline Sampel & IC $_{\mathbf{5 0}}(\boldsymbol{\mu g} / \mathbf{m L})$ & Intensitas Antioksidan \\
\hline Vitamin C & $3,933 \pm 0,013^{\mathrm{a}}$ & Sangat Kuat \\
Ekstrak Etanol Biji Limus (EBL) & $9,127 \pm 0,022^{\mathrm{b}}$ & Sangat Kuat \\
Nanopartikel Ekstrak Etanol Biji Limus (NEBL) & $1,166 \pm 0,021^{\mathrm{c}}$ & Sangat Kuat \\
\hline Keterangan: a; b; c; huruf yang berbeda menandakan perbedaan signifikan antar sampel (p<0,05)
\end{tabular}


DOI : https://doi.org/10.24843/JFU.2020.v09.i03.p02

pISSN: 2301-7716; eISSN: 2622-4607

Jurnal Farmasi Udayana, Spesial Issue Desember 2020, 144-151

\section{PEMBAHASAN}

Turunan senyawa polifenol termasuk didalamnya flavonoid dan tanin dapat menstabilkan radikal bebas dengan melengkapi kekurangan elektron yang dimiliki radikal bebas, dan menghambat terjadinya reaksi berantai dari pembentukan radikal bebas (Hanani, 2016). Monoterpen dan seskuiterpen merupakan komponen dari minyak atsiri yang telah banyak dilaporkan sebagai senyawa yang memiliki aktivitas antioksidan (Widayani, 2018). Senyawa kuinon merupakan senyawa berwarna mulai dari kuning hingga cokelat bahkan mendekati warna kehitaman, senyawa ini dapat bersifat sebagai inhibitor dalam reaksi radikal bebas, sehingga bertindak sebagai antioksidan (Weng, 1992 dan Harborne, 1987). Senyawa triterpenoid termasuk kedalam golongan senyawa terpen yang memiliki aktivitas antioksidan dengan mendonorkan atom hidrogen (Capelli, 2007). Indeks polidispersitas menggambarkan distribusi ukuran partikel yang ada dalam sediaan nanopartikel, semakin kecil jumLah indeks polidispersitas, semakin seragam ukuran partikel (Nurkhasanah, et al., 2015). Nilai indeks polidispersi 1 menunjukkan distribusi ukuran yang sangat luas dan mengandung partikel besar atau agregat yang dapat mengalami sedimentasi sedangkan nilai indeks polidispersi kurang dari 0,7 menunjukkan ukuran partikel yang seragam (Nindhin, et al., 2008). Nilai zeta potensial \pm 40 sampai \pm 60 memiliki arti bahwa sediaan nanopartikel memilki stabilitas yang baik (Pate \& Safier, 2016).

Pengujian aktivitas antioksidan pada penelitian ini menggunakan metode DPPH (1,1,2,2-diphenyl picryl hydrazyl). DPPH bertindak sebagai radikal bebas yang dapat bereaksi dengan senyawa yang dapat mendonorkan atom hidrogen. DPPH memberikan serapan pada panjang gelombang 515-520 nm (Sagar dan Singh,
2011). Ketika elektronnya berpasangan oleh keberadaan penangkap radikal bebas, maka absorbansinya menurun secara stokiometri sesuai dengan jumLah elektron yang diambil. Keberadaan senyawa antioksidan dapat mengubah larutan DPPH dari warna ungu menjadi kuning. Standar yang digunakan adalah vitamin $\mathrm{C}$ yang telah diketahui memiliki aktivitas antioksidan yang tinggi.

Sebelum pengujian aktivitas antioksidan dengan menggunakan metode DPPH dilakukan pengukuran operating time terlebih dahulu yang diplot selama selama 60 menit dengan selang waktu 5 menit. Operating time dilakukan untuk melihat waktu inkubasi terbaik dan optimal bereaksinya antara sampel dan DPPH. Berdasarkan hasil pengukuran diperoleh operating time pada menit ke 30 baik untuk asam askorbat maupun untuk sampel.

Aktivitas antioksidan dapat dilihat dari nilai IC $_{50}$. Nilai IC50 digunakan untuk menunjukan nilai konsentrasi yang mampu meredam $50 \%$ radikal bebas DPPH. Semakin kecil nilai IC 50 yang kurang dari 50 $\mu \mathrm{g} / \mathrm{mL}$ maka senyawa tersebut memilki potensi aktivitas antioksidan yang sangat kuat (Prakash, 2001).

Berdasarkan Gambar 1 dapat terlihat bahwa aktivitas antioksidan paling baik ditunjukkan oleh NEBL, yang ditandai pula dengan nilai IC50 paling rendah pada tabel 2. Hasil analisis statistik menunjukkan bahwa semua sampel uji memiliki nilai IC $_{50}$ yang berbeda signifikan $(p<0,05)$. Nanopartikel esktrak biji limus (NEBL) memiliki aktivitas antioksidan yang lebih kuat dibandingkan ekstrak biji limus dan standar vitamin $C \quad(p<0,05)$. Hal tersebut menunjukkan bahwa upaya peningkatan aktivitas antioksidan dengan memodifikasi sediaan ekstrak menjadi nanopartikel ekstrak berhasil sesuai dengan hipotesa. Peningkatan aktivitas antioksidan dikarenakan nanopartikel dapat 
DOI : https://doi.org/10.24843/JFU.2020.v09.i03.p02

pISSN: 2301-7716; eISSN: 2622-4607

Jurnal Farmasi Udayana, Spesial Issue Desember 2020, 144-151

meningkatkan luas permukaan dari ekstrak, sehingga kontak antara senyawa antioksidan dan radikal bebas lebih besar dan lebih aktif dalam penurunan efek radikalnya (Biswas, 2014). Selain itu aktivitas antioksidan dari ekstrak dapat ditingkatkan dengan pembuatan sediaan nanopartikel karena kemampuan sediaan nanopartikel dalam meningkatkan kestabilan senyawa antioksidan (Mappamasing dkk, 2015). Hal ini dapat terjadi karena adanya interaksi elektrostatik antara kelompok amina kitosan yang bermuatan positif yang terprotonasi dalam kondisi asam dan atom oksigen dalam struktur senyawa flavonoid/polifenol yang TPP menstabilkan interaksi ini (Nurkhasanah, 2015).

\section{KESIMPULAN}

Modifikasi ekstrak biji limus menjadi sediaan nanopartikel ekstrak biji limus dapat meningkatkan aktivitas antioksidan yang diuji secara invitro menggunakan metode DPPH. Nanopartikel ekstrak biji limus memiliki potensi yang sangat baik sebagai antioksidan alami berdasarkan hasil analisis statistik yang menunjukkan aktivitas antioksidan yang lebih kuat dibandingkan standar vitamin $C(p<0,05)$.

\section{UCAPAN TERIMAKASIH}

Terimaksih kami ucapkan kepada KEMENRISTEK DIKTI yang telah memberikan dana hibah kepada kami, dimana penelitian ini merupakan bagian dari penelitian dosen pemula. Ucapan terimakasih juga untuk STIKes BTH atas segala bentuk dorongan dan fasilitas yang diberikan kepada kami.

\section{DAFTAR PUSTAKA}

1. Abdassah, Marline. (2017). Nanopartikel Dengan Gelasi Ionik. Farmaka; 15 (1): 45-52.

2. Agoes, Goeswin. (2008). Sistem Penghantaran Obat Pelepas Terkendali.
Bandung: ITB Press.

3. Atun, Sri dan Sri Handayani. (2017). Synthesis of Nanoparticles Produced by Ethanol Extract of Boesenbergia rotunda Rhizome Loaded with Chitosan and Alginic Acid and its Biological Activity test. Pharmacogn J. 2017; 9 (2): 142-147. doi.org/10.5530/pj.2017.2.24

4. Biswas, AK, MDR Islam, ZS Choudhury, $S$ Mostofa, MF Kadir . (2014). Nanotechnology Based Approaches in Cancer Therapeutics. Adv. Nat. Sci; 5(4): $1-11$. doi.org/10.1088/2043$\underline{6262 / 5 / 4 / 043001}$

5. Hanani, Endang. (2016). Analisi Fitokimia. Jakarta: EGC.

6. Harborne. (1987). Metode Fitokimia Penuntun Cara Modern Menganalisis Tumbuhan, Edisi kedua, Hal 5, 69-76, diterjemahkan oleh Kosasih Padmawinata dan Iwang Soedira, ITB Press, Bandung.

7. Kurniasih M, P Purwati, RS Dewi, S Fatimah. (2018). Uji Aktivitas Antioksidan N-Metil Kitosan Berkelarutan Tinggi. ALCHEMY Jurnal Penelitian Kimia; 14(1): 107-118. doi.org/10.20961/alchemy.14.1.15100.1 $\underline{07-118}$

8. Mappamasing F, E Anwar, A Mun'im. (2015). Formulasi, Karakterisasi dan Uji Penetrasi In Vivo Resveratrol Solid Lipid Nanopartikel dalam Krim Topikal. Jurnal Ilmu Kefarmasian Indonesia; 13(2): 137144.

9. Mulangsri DAK, A Budiarti, EN Saputri. (2017). Aktivitas Antioksidan Fraksi Dietileter Buah Mangga Arumanis (Mangifera indica L.) dengan Metode DPPH. Jurnal Pharmascience; 04 (01): 85 - 93. doi.org/10.20527/jps.v4i1.5760

10. Munawar A, Mohammed, JTM Syeda, KM Wasan, EK Wasan. (2017). An Overview of Chitosan Nanoparticles and Its Application in Non-Parenteral Drug Delivery. Pharmaceutis 2017; 9 (53): 126. 
DOI : https://doi.org/10.24843/JFU.2020.v09.i03.p02

pISSN: 2301-7716; eISSN: 2622-4607

Jurnal Farmasi Udayana, Spesial Issue Desember 2020, 144-151

doi.org/10.3390/pharmaceutics9040053

11. Nidhin, M, Sreeram K. J, Indumathy R dan Nair B U. (2008). Syntesis Of Iron Oxide Nanoparticles Of Narrow Size Distribution On Polysaccharide Templates. Bulletin of Materials Science, $31(1)$ 93-96. https://doi.org/10.1007/s12034-0080016-2

12. Nurkhasanah, Tedjo Yuwono, Laela Hayu Nurani, Muhammad Ikhwan Rizki, Krisana Kraisintu. (2015). The Development of Chitosan Nanoparticles From Hibiscus Sabdariffa L Calyx Extract From Indonesia And Thailand. IJPSR; 6(5): 1855-1861. DOI: 10.13040/IJPSR.0975-8232.6(5).185561

13. Nurviana, Vera. (2016). Profil Farmakognosi dan Skrining Fitokimia dari Kulit, Daging, dan Biji Buah Limus (Mangifera foetida Lour). Jurnal Kesehatan Tunas Husada; 16 (1): 136142. doi.org/10.36465/jkbth.v16i1.176

14. Nurviana V, AY Aprilia, EK Nuraini. (2018). Skrining Aktivitas Antioksidan Fraksi Ekstrak Etanol Kernel Biji Limus. Pharma Xphore; 3(2): 216-223.

15. Pate, K, P. Safier. (2016). Chemical Metrology Methods for CMP Quality. Elsevier, 299-325. https://doi.org/10.1016/B978-0-08100165-3.00012-7

16. Sagar, B.K., Singh, R.P. (2011). Genesis and development of DPPH method of antioxidant assay. JFood Sci

17. Taurina W, R Sari, UC Hafinur, S Wahdaningsih, Isnindar. (2017). Optimasi Kecepatan Dan Lama Pengadukan Terhadap Ukuran Nanopartikel Kitosan-Ekstrak Etanol This work is licensed under a Creative Commons Attribution 4.0 International License

18. 70\% Kulit Jeruk Siam (Citrus Nobilis L.Var Microcarpa). Trad. Med. J.,
January; $\quad 22(1)$ : $\quad 16-20$.

doi.org/10.22146/tradmedj.24302

19. Widayani, Anis, Edy Cahyono, Harjono. (2018). Isolasi dan Uji Antioksidan Weng, Xin Chu dan Michael H. Gordon. (1992). Antioxidant Activity of Quinones Extracted from Tanshen (Salvia miltiorrhiza Bunge). J. Agric. Food Chem: $\quad 40 \quad$ (8); 1331-1336. doi.org/10.1021/jf00020a007

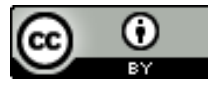

This work is licensed under a Creative Commons Attribution 4.0 International License 